Review artikel

\title{
Menangkap nilai sosial dari SROI
}

Wina Illirian Sevi Rahmadanti

Email : illiriansevi@gmail.com

Social Return on Investmen memberikan kerangka kerja untuk mengukur dampak sosial suatu komunitas program pembangunan dengan memasukkan sosial lingkungan dan ekonomi biaya dan keuntungan. SROI bercerita tentang bagaimana perubahan diciptakan mengukur hasil sosial, lingkungan dan ekonomi dan menggunakan moneter nilai untuk mewakili mereka. (nicholls,2014)

Konsep nilai sosial tumbuh dari ide awal tanggung jawab perusahaan, ekonomi etis, dan perusahaan sosial dan literatur penilaian. Ambiguitas konseptualnya dibuat nyata sebagai produk dan layanan yang dihasilkan oleh perusahaan organisasi yang bernilai bagi masyarakat luas. SROI adalah metodologi dampak sosial yang memungkinkan organisasi nirlaba membuktikan nilai pekerjaan mereka yang lebih luas.

Ini didasarkan pada analisis biaya-manfaat tradisional dan memberikan nilai moneter pada pengembalian sosial menggunakan proksi keuangan, yang dibandingkan dengan tingkat investasi untuk menghasilkan rasio. SROI biaya terhadap hasil sosial. Ini awalnya dikembangkan oleh Roberts Enterprise Development Fund (REDF) di AS pada pertengahan 1990-an. Baru-baru ini, penekanan pada keterlibatan pemangku kepentingan dengan menggunakan metodologi standar telah berkembang melalui karya New Economics Foundation (nef) di Inggris.

Investasi dalam pengurangan limbah padat berbahaya dan kinerja keuangan perusahaan terpilih yang terdaftar di indeks investasi bertanggung jawab sosial bursa efek johannesburg Studi ini mengambil sampel 64 perusahaan pertambangan dan manufaktur yang terdaftar di Indeks Investasi Tanggung Jawab Sosial di Bursa Efek Johannesburg dari 2008 hingga 2017. Dengan menggunakan analisis Data Panel, hasil menunjukkan bahwa setiap investasi tidak signifikan untuk menjelaskan perubahan laba atas aset. Hasil penelitian menunjukkan bahwa pembuangan limbah padat berbahaya melalui investasi yang ditargetkan mengurangi risiko kewajiban di masa depan, misalnya, tuntutan lingkungan, pemogokan dan denda untuk kerusakan lingkungan, dan secara signifikan dapat mempengaruhi pengembalian aset. Hasil penelitian juga dalam sinergi dan evaluasi kinerja antara dana islam dan investasi yang 
bertanggung jawab secara sosial. Keterhubungan statis dan dinamis dari investasi lingkungan, sosial, dan tata kelola bukti internasional. kami memeriksa apakah investasi ini rentan terhadap guncangan ekonomi dan keuangan eksogen yang serupa dengan rekan konvensional mereka.

Penelitian pasca-hunian yang ada terkait dengan prioritas pengguna di gedung-gedung belum mencapai penyebaran yang signifikan dalam lingkaran pembelajaran desain perkotaan berkelanjutan. Konsep nilai sosial yang baru muncul di Inggris memiliki potensi yang signifikan untuk mengatasi masalah dampak evaluatif dalam penelitian desain bangunan. Landasan konseptual pengaitan nilai sosial dengan bidang penelitian ini dibangun melalui sintesis pemikiran mutakhir dalam penelitian pasca hunian dalam kaitannya dengan nilai sosial, menekankan pada kurangnya penelitian yang mengakui sosialitas masyarakat pengguna.

\section{DAFTAR PUSTAKA}

\section{Reference}

Pratono, A.H., Suyanto, D Marciano, Zurbrügg, C. (2017) The Hong Kong Journal of Social Work $51(01 \mathrm{n} 02), 93-114$

Watson, kelly, J, Evans, j, Korvonen A, Whitley, T, (2016) Capturing The Social Value of Buildings. (13), pp. 289-301

Fakoya, B.M., (2020) Investment in Hazardous Solid Waste Reduction and Financial Performance of Selected Companies Listed in The Johannesburg Stock Exchange Socially Responsible Investmen Index. (23), 21-29

Yesuf, J.A., Aassouli D. (2020) Exploring Synergies and Performance Evaluation Between Islamic Funds and Socially Responsible Invesment in Light of The Sustainable Developments Goals. (6) (e04562), 8

Umar, Z., Kenourgios, D, Papathanasio, S. (2020) The Static Dynamic Connectedness of Environmental, Social, and Governance Investment International Evidence. (93), 112-124 
